\title{
Distribution, Habitat, and Productivity of Tundra Swans on Victoria Island, King William Island, and Southwestern Boothia Peninsula, N.W.T.
}

\author{
D. BRUCE STEWART ${ }^{1}$ and LIONEL M.J. BERNIER ${ }^{2}$
}

\author{
(Received 21 July 1988; accepted in revised form 10 March 1989)
}

\begin{abstract}
Data on tundra swans (Cygnus columbianus columbianus) were recorded in the central and eastern Canadian Arctic, south of $77^{\circ} \mathrm{N}$ latitude, and on Southampton Island during the summers of 1980-85. Swans were seen on Victoria, Royal Geographical Society, King William, Stanley, and Southampton islands and on southwestern Melville and Boothia peninsulas. Most swans inhabited low-lying areas that were inundated by the sea following glaciation and are now dotted with shallow tundra ponds. Breeding swans were common in the Minto Inlet, Lady Franklin Point, and Cambridge Bay areas of Victoria Island and on King William Island and southwestern Boothia Peninsula. In August, $52-89 \%$ of the adults and subadults in these areas were seen as potential breeders, and the remainder were in nonbreeding flocks. Between 17 and $33 \%$ of the pairs had cygnets, and 10-13\% of all swans were cygnets. With brood sizes of $1-3$ (1.5 $\pm 0.7[\bar{X} \pm$ SD] to 1.6 \pm 0.5 ), the apparent breeding success was low relative to other northern swan populations. However, these breeding populations are significant and should be considered in management plans for the eastern population of the tundra swan.
\end{abstract}

Key words: arctic birds, Canada, Cygnus columbianus columbianus, distribution, habitat, Northwest Territories, productivity

RÉSUMÉ. On a relevé des données sur les cygnes siffleurs (Cygnus columbianus columbianus) dans le centre et l'est de l'Arctique canadien, au sud du $77^{\mathrm{e}}$ parallèle, et dans l'île de Southampton, au cours des étés de 1980 à 1985 . On a aperçu des cygnes dans les îles Victoria, Royal Geographical Society, King William, Stanley et Southampton ainsi qu'au sud-ouest des péninsules de Melville et de Boothia. La piupart des cygnes habitaient des zones surbaissées, inondées par la mer après la glaciation, qui sont maintenant parsemées d'étangs de toundra peu profonds. Les cygnes reproducteurs se retrouvaient fréquemment aux environs de Minto Inlet, de Lady Franklin Point et de Cambridge Bay dans l'île Victoria ainsi que dans l'île King William et le sud-ouest de la péninsule de Boothia. En août, de 52 à $89 \%$ des adultes et jeunes adultes de ces régions apparaissaient comme des reproducteurs potentiels, et le reste se retrouvait dans des groupes non reproducteurs. De 17 à $33 \%$ des couples avaient des jeunes cygnes, et de 10 à $13 \%$ de tous les cygnes étaient des jeunes. Avec des nichées de 1 à 3 individus $(1,5 \pm 0.7[\bar{x} \pm \sigma]$ à $1,6 \pm 0,5)$, le taux apparent de réussite quant à la reproduction était bas comparé à celui d'autres populations de cygnes nordiques. Ces populations reproductrices sont cependant importantes et l'on devrait en tenir compte dans les programmes de gestion de la population de cygnes siffleurs de l'est de la région.

Mots clés: oiseaux arctiques, Canada, Cygnus columbianus columbianus, distribution, habitat, Territoires du Nord-Ouest, productivité

Traduit pour le journal par Nésida Loyer.

\section{INTRODUCTION}

Most tundra swans (Cygnus columbianus columbianus) in North America breed north of the tree line, many of them in the Canadian Arctic east of the Mackenzie Delta. They migrate northward in the spring, arriving in late May or early June to spend the summer in lowland coastal areas that are dotted with shallow tundra ponds. They remain there to breed and/or molt until late August or September and then migrate southward to overwinter (Bellrose, 1976).

During the summer tundra swans are widely distributed in the southern Canadian arctic islands and along the coastal mainland of northern Canada (Manning et al., 1956; Fraser, 1957; Barry, 1960; Parmelee et al., 1967; Lumsden, 1975, 1984; Allen and Hogg, 1978; McLaren and Alliston, 1981, 1985; McLaren and McLaren, 1984; Gaston et al., 1986). However, because of the difficulties inherent in arctic travel, the extent of swan breeding areas in the Canadian Arctic, particularly on Victoria Island (Godfrey, 1986), remains to be delineated. It is important that the extent of these breeding areas be identified before northern development adversely affects populations of the tundra swan.

Research on aquatic resources in the Northwest Territories afforded us the opportunity to record data on swans inhabiting the central and eastern Arctic, south of $77^{\circ} \mathrm{N}$ latitude, and Southampton Island during the summers of 1980-85. This paper documents our observations on the dis- tribution, habitat, and productivity of swans in these areas and compares these findings with other studies.

\section{METHODS}

Observations of tundra swans were made on an opportunistic basis during flights in a Bell $206 \mathrm{~L}$ helicopter to and from aquatic sampling sites (Fig. 1). The work was conducted from July through September of 1980-85 with a different area of northern Canada surveyed each year (Table 1). Observers on each side of the helicopter recorded observations on 1:250000 scale maps and care was taken to ensure that sightings were not duplicated on those or subsequent flights. All swans observed from the air were assumed to be tundra swans; that assumption proved true in all cases that could be verified from the ground using binoculars.

Flying time in a given area varied, and in most areas a variety of coastal and inland habitats was covered (Table 1; Fig. 1). The altitude above ground, flight speed, and visibility varied during the surveys.

Data were gathered on pairs, singles, broods, and flocks of swans. The proportion of pairs with cygnets (young) was calculated by dividing the number of broods by the number of pairs of potential breeders (Lensink, 1973; Wilk, 1988). The potential breeding pairs included all pairs and half of the singles, since singles were considered to be half of a breeding pair. The pairs count included some prebreeders

\footnotetext{
${ }_{1}^{1}$ Arctic Biological Consultants, 95 Turnbull Drive, Box 68, St. Norbert Postal Stn., Winnipeg, Manitoba, Canada R3V 1L5

${ }^{2}$ Komuk Biological Consultants, 669 River Drive, Box 386, Lorette, Manitoba, Canada R0A 0Y0

(C) The Arctic Institute of North America
} 


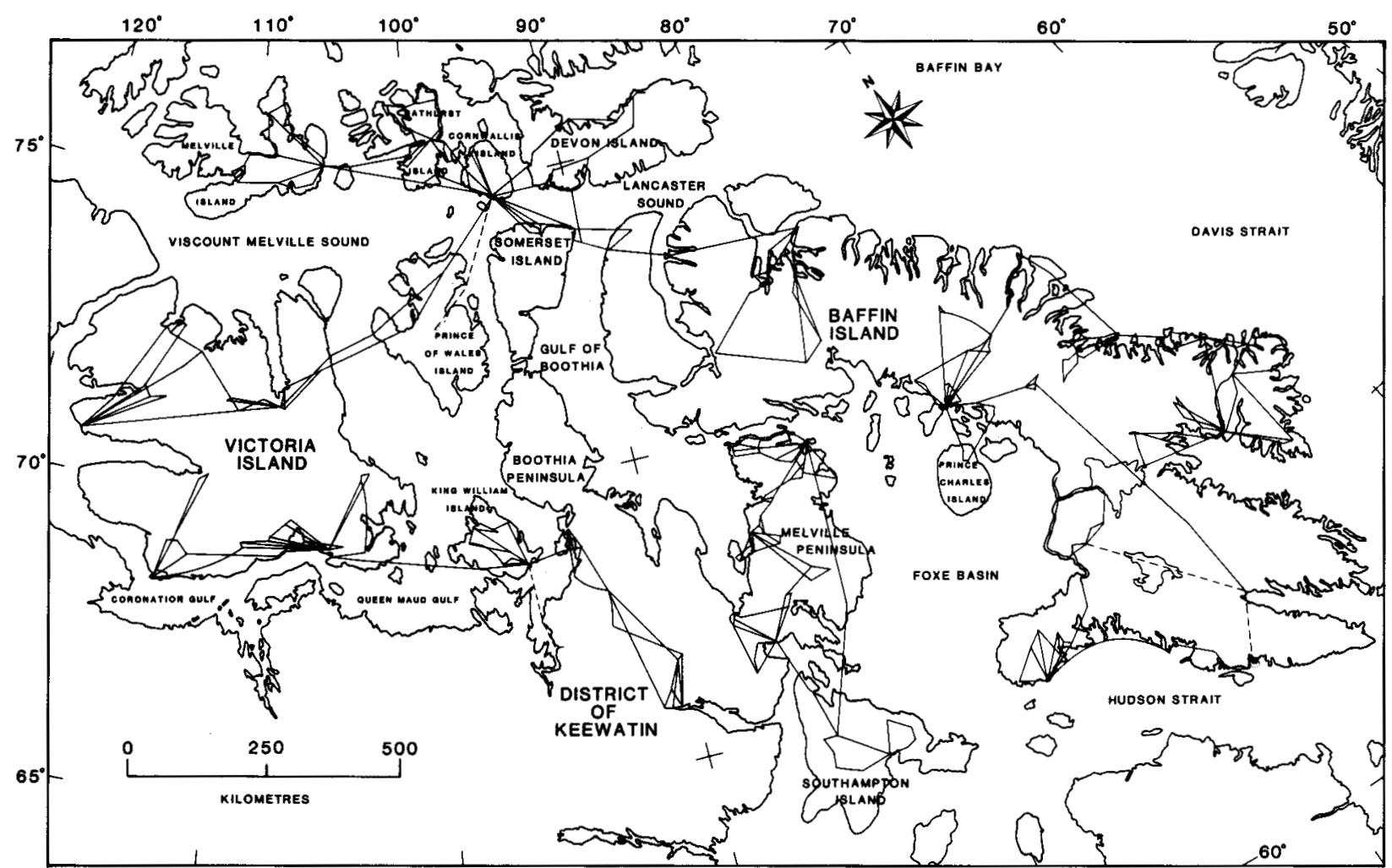

FIG. 1. Flight paths taken by helicopter (solid line) or fixed-wing aircraft (dashed line) during aquatic resource surveys conducted between July and early September 1980-85.

TABLE 1. Location, observation period (day/mo/yr), and flying time $(\mathrm{h})$ in areas where tundra swans were recorded, 1980-85

\begin{tabular}{lrr}
\hline \hline Area & Observation period $^{1}$ & Flying time \\
\hline Devon Island & $31 / 7-9 / 8 / 80$ & 20 \\
Cornwallis Island (south \& east) & $1-12 / 8 / 80$ & 7 \\
& $19 / 7-2 / 8 / 81$ & 5 \\
Little Cornwallis Island & $1-2 / 8 / 81$ & 2 \\
Bathurst Island & $19-31 / 8 / 81$ & 14 \\
Melville Island & $20-24 / 8 / 81$ & 23 \\
Victoria Island (north) & $6-13 / 8 / 81$ & 33 \\
$\quad$ (south) & $3-28 / 8 / 82$ & 35 \\
Royal Geographical Society Islands & $26 / 8 / 82$ & $<1$ \\
Prince of Wales Island & $6-13 / 8 / 81$ & 3 \\
King William Island & $15-26 / 8 / 82$ & 12 \\
Somerset Island & $13-18 / 8 / 80$ & 3 \\
Boothia Peninsula-Wager Bay & $19-26 / 8 / 82$ & 22 \\
Repulse Bay area & $29 / 8-3 / 9 / 83$ & 13 \\
Melville Peninsula & $15 / 8-8 / 9 / 83$ & 34 \\
Southampton Island & $4-8 / 9 / 83$ & 14 \\
Baffin Island (north) & $18-29 / 8 / 80$ & 35 \\
$\quad$ (central) & $19 / 7-15 / 8 / 85$ & 77 \\
$\quad$ (south) & $18 / 8-2 / 9 / 84$ & 21 \\
\hline \hline
\end{tabular}

$\overline{1}$ These are the earliest and latest dates on which each area was visited.

that established territories but could not be distinguished from adult pairs. Swans in flocks were primarily nonbreeders.

\section{RESULTS AND DISCUSSION}

\section{Distribution}

Tundra swans were observed on Victoria, Royal Geographical Society, King William, Stanley, and Southampton islands and on Boothia and Melville peninsulas (Table 2; Figs.
2 and 3). Swans were not seen on Melville, Bathurst, Cornwallis, Little Cornwallis, Devon, Baffin, Wales, Prince of Wales, or Somerset islands. With the notable exception of the Foxe Basin coast of Baffin Island, where extensive coastal lowlands provide breeding habitat for many geese and some swans (Gaston et al., 1986), these latter areas offer less suitable habitat and fewer days with mean temperatures greater than $0^{\circ} \mathrm{C}$ (Maxwell, 1981). Swans have been seen on Melville (Sabine, 1824), Bathurst (R. Decker, unpubl. data), Prince of Wales (Manning and Macpherson, 1961; T.W. Barry, unpubl. data), and northern Baffin (Mary-Rousselière and Heyland, 1973) islands.

\section{Habitat}

With a few exceptions, the swans occurred in low-lying coastal areas. Indeed, $79 \%$ of the swans occurred at elevations of less than $60 \mathrm{~m}$ above sea level (as1), $17 \%$ between 60 and $120 \mathrm{~m}, 4 \%$ between 120 and $300 \mathrm{~m}$, and none was observed at elevations greater than $300 \mathrm{~m}$. The distribution of breeding pairs was similar, and all of the swans at higher elevations $(>120 \mathrm{~m}$ ) were seen on Victoria Island. Ponds above $100 \mathrm{~m}$ in elevation generally lacked adequate emergent and shoreline vegetation for feeding, nesting, and cover, but there were small vegetated wetlands on upland areas of Victoria Island. Swans were common in the interior of King William Island, which is less than $100 \mathrm{~m}$ asl. In the Bristol Bay area of Alaska, Wilk (1988) found breeding swans in most wetland habitats below $100 \mathrm{~m}$ asl and only one pair at $183 \mathrm{~m}$.

Virtually all of the swans occurred in areas that were inundated by the sea following the Wisconsin glaciation and 
have subsequently rebounded (Andrews, 1972). Ponds and lakes in these areas tend to be shallow and have lush patches of shoreline vegetation. Their waters, and probably their soils, are rich in calcium (Stewart and Bernier, 1982, $1983,1984)$, which the swans require for egg production. Similar trends in habitat use have been observed among swans in Foxe Basin (Gaston et al., 1986) and Hudson Bay (Lumsden, 1984).

Ponds or lakes used by the swans were often shallow and subject to fish winterkill (Stewart and Bernier, 1982, 1983, 1984). Many had surface areas of less than 10 hectares and became turbid when winds stirred up the bottom sediment. They were commonly inhabited by at least one macroinvertebrate species - for example, the crustaceans Mysis relicta, Gammarus lacustris, Branchinecta paludosa, or Lepidurus arcticus - but few, if any, supported aquatic macrophytes. There were patches of tundra vegetation along their shores, and swans were often seen grazing or resting on gradually sloping areas of grasses, sedges, or moss near the water, sometimes near a large nest. None of the small ponds supported more than a single breeding pair.

\section{Productivity}

Swans with cygnets were seen in the Lady Franklin Point, Minto Inlet, and Cambridge Bay areas of Victoria Island; on Royal Geographical Society, King William, and Southampton islands; and on southwestern Boothia Peninsula (Table 2).

It was not possible to accurately determine breeding effort or success, since most of our swan records were based on August sightings. However, $63 \%$ of the swans seen on Victoria Island were paired and $33 \%$ of those pairs were accompanied by cygnets. This compares to 52 and $29 \%$ respectively for King William Island, and 89 and $17 \%$ for Boothia Peninsula. Similar proportions were observed in August on the Yukon Delta of Alaska (22-95\% paired, $15-48 \%$ with broods; Lensink, 1973) and on the northern Alaska Peninsula (50-67\% paired, 25-55\% with broods; Wilk, 1988).

In August, cygnets constituted $13 \%$ of all swans observed on Victoria Island, $10 \%$ on King William Island, and $11 \%$ on Boothia Peninsula - half the percentage found in Alaska's Bristol Bay population in July (24-28\%; Wilk, 1988). Brood sizes ranged from 1 to 3 , with averages of 1.5 cygnets per family on Victoria and King William islands and $\mathbf{1 . 6}$ on
Boothia Peninsula (Table 2). The apparent breeding success was low relative to swans observed in August on the Rasmussen Lowlands of Boothia Peninsula (1.6-2.5, $\mathrm{n}=2 \mathrm{yr}$; McLaren and McLaren, 1984), the northeastern coast of Hudson Bay (2.8-3.7, $\mathrm{n}=3 \mathrm{yr}$; Heyland et al., 1970), the northern Alaska Peninsula (2.7-3.3, $\mathrm{n}=4 \mathrm{yr}$; Wilk, 1988), and the Yukon Delta of Alaska (2.6-3.6, $\mathrm{n}=9 \mathrm{yr}$; Lensink, 1973). This may be attributable to later springs in the northern part of their range rather than to predation or disease. Lensink (1973) found that a late spring ice break-up caused by low temperatures reduced both the proportion of the swans that nested and the size of clutches.

Cygnets were flightless throughout August and into early September. Swans without broods were in flying flocks of up to 33 birds by mid-August and were moving southward in late August and early September on both Victoria and King William islands.

\section{Population Management}

No population estimates are possible from our data. However, the estimated number of swans on King William Island was 300 in 1960 (Barry, 1960) and between 1000 and 2000 in 1982 (R. Decker, unpubl. data). This may reflect a substantial increase in the eastern population of tundra swans, which, based on winter surveys, increased from an estimated 41000 birds in 1960 to 73000 in 1982 (United States Department of the Interior, 1988). In 1988 the eastern population was an estimated 77100 birds (J.R. Serie, unpubl. data).

The presence of breeding tundra swans in the Lady Franklin Point, Minto Inlet, and Cambridge Bay areas of Victoria Island; on Royal Geographical Society, King William, and Southampton islands; and on western Boothia Peninsula reaffirms the importance of these areas as swan breeding habitats (Figs. 2 and 3). These populations are more extensive than we thought and should be considered in management plans for the eastern population of the tundra swan.

Tundra swans are hunted for food by Inuit in many northern communities (Brice-Bennett, 1976; Jacobson, 1980; Gamble, 1987). As populations in the communities increase and hunting technologies improve, it is important that the hunting be managed to prevent the over-exploitation and subsequent disappearance of swans from an area - such as occurred in the Hudson Bay-James Bay region during the last century (Lumsden, 1975, 1984).

TABLE 2. Observation period (day/mo/yr), location seen, number (n), and brood size ( $\overline{\mathrm{X}} \pm \mathrm{SD}$ ) of tundra swans in northern Canada, 1980-85

\begin{tabular}{|c|c|c|c|c|c|c|}
\hline Period & Location & Swans in flocks & Pairs or singles & Cygnets & Total swans & Brood size \\
\hline $\begin{array}{l}6-13 / 8 / 81 \\
3-28 / 8 / 82\end{array}$ & Victoria Island & 98 & 166 & 41 & 305 & $1.5 \pm 0.7(27)^{1}$ \\
\hline $26 / 8 / 82$ & Royal Geographical Society Islands & 0 & 2 & 1 & 3 & $1.0(1)$ \\
\hline $15-26 / 8 / 82$ & King William Island & 199 & 219 & 47 & 465 & $1.5 \pm 0.6(32)$ \\
\hline $26 / 8 / 82$ & Stanley Island & 0 & 1 & 0 & 1 & \\
\hline $22-26 / 8 / 82$ & Boothia Peninsula & 7 & 58 & 8 & 73 & $1.6 \pm 0.5(5)$ \\
\hline $3 / 9 / 83$ & Melville Peninsula ${ }^{2}$ & 0 & 1 & 0 & 1 & \\
\hline $7 / 9 / 83$ & Southampton Island ${ }^{3}$ & 0 & 6 & 6 & 12 & $3.0 \pm 0.0(2)$ \\
\hline
\end{tabular}

${ }^{1}$ Number of broods in parentheses.

${ }^{2}$ This swan was seen at the head of Committee Bay on the west side of Melville Peninsula $\left(67^{\circ} 11^{\prime} \mathrm{N}, 87^{\circ} 32^{\prime} \mathrm{W}\right)$.

${ }^{3}$ These swans were seen on the Boas River between $64^{\circ} 14^{\prime} \mathrm{N}, 84^{\circ} 52^{\prime} \mathrm{W}$ and $64^{\circ} 37^{\prime} \mathrm{N}, 85^{\circ} 18^{\prime} \mathrm{W}$. 


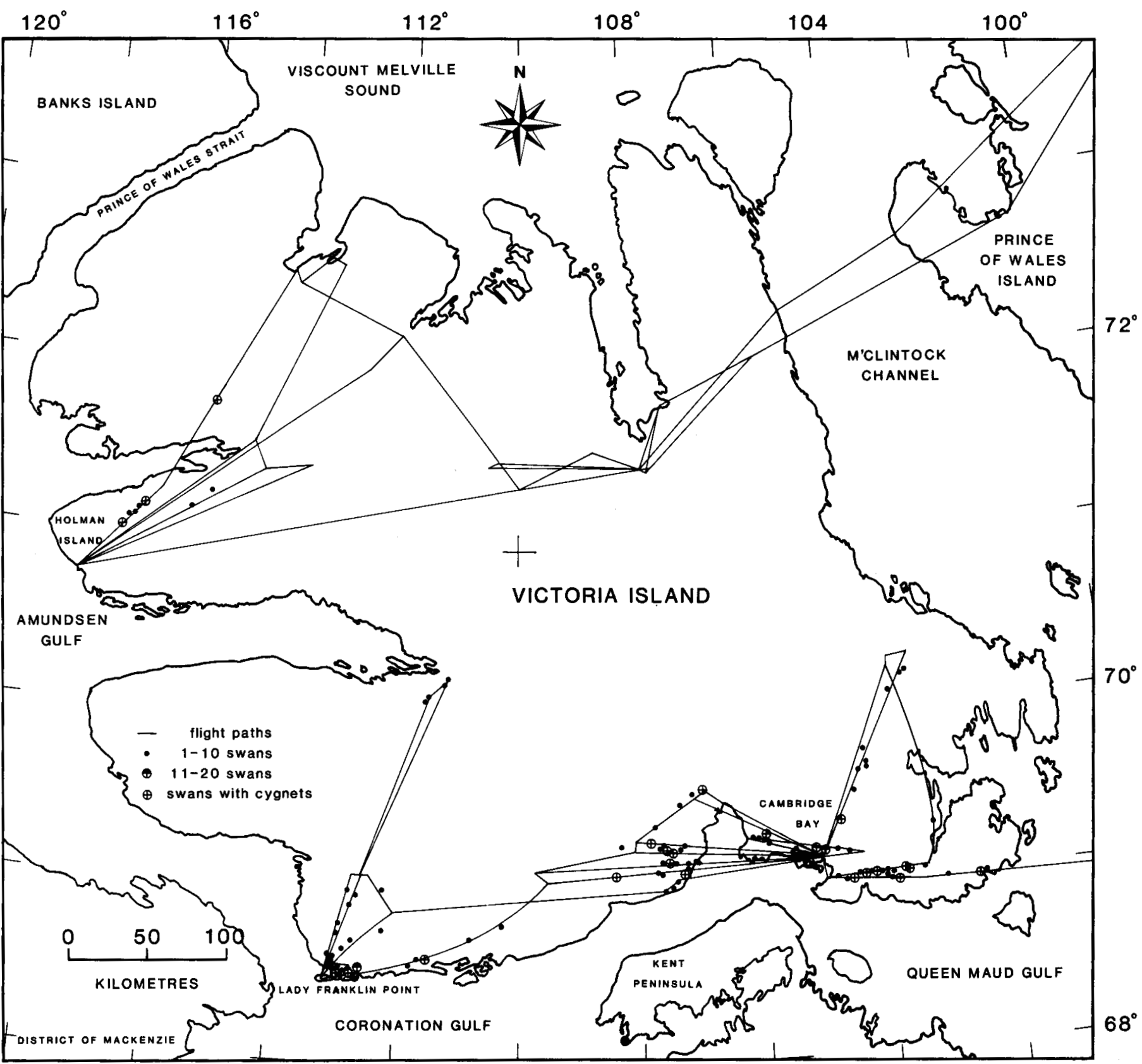

FIG. 2. Flight paths and distribution of sightings of tundra swans on Victoria Island, N.W.T.

\section{ACKNOWLEDGEMENTS}

These observations were made during our work with the Northern Land Use Information Series mapping program (Environment Canada; Indian and Northern Affairs Canada), using helicopter support and accommodations provided by the Polar Continental Shelf Project (Energy, Mines and Resources Canada) and other accommodations and support provided by the federal Department of National Defence and Fisheries and Oceans Canada. We thank Gary MacDonald for helping with aerial observations in 1980 and Thomas Barry, Bob Bromley, Austin Reed, and Randall Wilk for their constructive criticisms of the manuscript.

\section{REFERENCES}

ALLEN, D.L., and HOGG, T.H. 1978. Bird studies in the Keewatin District. Fisheries and Environment Canada for the Aretic Islands Pipeline Program, ESCOM Report No. AI-27. 129 p. Available at Department of Fisheries and Oceans Library, 501 University Crescent, Winnipeg, Manitoba R3T 2N6.

ANDREWS, J.T. 1972. Post-glacial rebound. In: The National Atlas of Canada. Ottawa: Department of Energy, Mines and Resources. 35-36. BARRY, T.W. 1960. Waterfowl reconnaissance in the western Arctic. Arctic Circular 13:51-58.

BELLROSE, F.C. 1976. Ducks, geese, and swans of North America. Harrisburg, Pennsylvania: Stackpole Company. 544 p. 


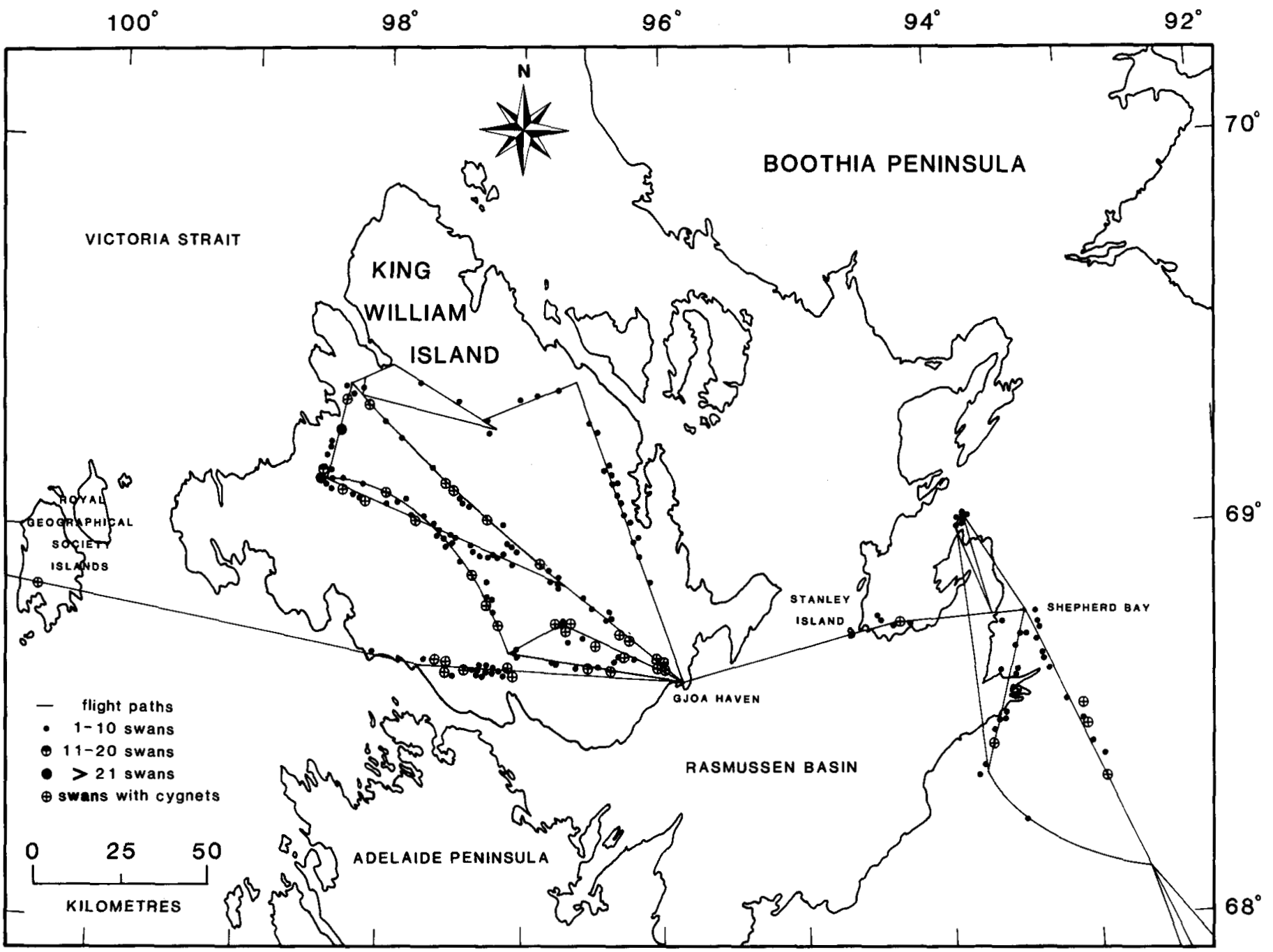

FIG. 3. Flight paths and distribution of sightings of tundra swans on Royal Geographical Society, King William, and Stanley islands and on Boothia Peninsula, N.W.T.

BRICE-BENNETT, C. 1976. Inuit land use in the east-central Canadian Arctic. In: Freeman, M.M.R., ed. Inuit land use and occupancy. Vol. 1. Ottawa: Department of Indian and Northern Affairs. 63-71.

FRASER, J.K. 1957. Birds observed in the central Canadian Arctic, 1953, 1955, 1956. Canadian Field-Naturalist 71:192-199.

GAMBLE, R.L. 1987. Native harvest of wildlife in the Keewatin Region, Northwest Territories for the period October 1984 to September 1985. Canadian Technical Report of Fisheries and Aquatic Sciences $1544.59 \mathrm{p}$.

GASTON, A.J., DECKER, R., COOCH, F.G., and REED, A. 1986. The distribution of larger species of birds breeding on the coasts of Foxe Basin and northern Hudson Bay, Canada. Arctic 39:285-296.

GODFREY, W.E. 1986. The birds of Canada. Ottawa: National Museum of Canada. 595 p.

HEYLAND, J.D., CHAMBERLAIN, E.B., KIMBALL, C.F., and BALDWIN, D.F. 1970. Whistling swans breeding on the northwest coast of New Quebec. Canadian Field-Naturalist 84:398-399.

JACOBSON, R. 1980. Land use for resource harvesting on Victoria Island, Northwest Territories, 1980. Report prepared for Polar Gas Project, Socioeconomic Program. 70 p. Available at University of Winnipeg Library, 515 Portage Avenue, Winnipeg, Manitoba R3B 2E9.

LENSINK, C.J. 1973. Population structure and productivity of whistling swans on the Yukon Delta, Alaska. Wildfowl 21:21-26.

LUMSDEN, H.G. 1975. The whistling swan in James Bay and the southern region of Hudson Bay. Arctic 28:194-200.
1984. The pre-settlement breeding distribution of trumpeter, Cygnus buccinator, and tundra swans, C. columbianus, in eastern Canada. Canadian Field-Naturalist 98:415-424.

MANNING, T.H., and MACPHERSON, A.H. 1961. A biological investigation of Prince of Wales Island. Transactions of the Royal Canadian Institute 33:116-239.

MANNING, T.H., HÖHN, E.O., and MACPHERSON, A.H. 1956. The birds of Banks Island. National Museum of Canada Bulletin 143. $144 \mathrm{p}$.

MARY-ROUSSELIERE, G., and HEYLAND, J.D. 1973. The whistling swan nesting in northern Baffin Island, Northwest Territories. Canadian FieldNaturalist 88:92.

MAXWELL, J.B. 1981. Climatic regions of the Canadian Arctic islands. Arctic 34:225-240.

McLAREN, M.A., and ALLISTON, W.G. 1981. Summer bird populations on western Victoria Island, N.W.T. Prepared by LGL Limited for the Polar Gas Project. 147 p. Available at University of Winnipeg Library, 515 Portage Avenue, Winnipeg, Manitoba R3B 2E9.

1985. Effects of snow and ice on waterfowl distribution in the central Arctic Islands. Arctic 38:43-52.

McLAREN, M.A., and McLAREN, P.L. 1984. Tundra swans in northeastern Keewatin District, N.W.T. Wilson Bulletin 96:6-11.

PARMELEE, D.F., STEPHENS, H.A., and SCHMIDT, R.H. 1967. The birds of southeastern Victoria Island and adjacent small islands. National Museum of Canada Bulletin 222. 229 p. 
SABINE, E. 1824. Birds. In: A supplement to the appendix of Captain W.E. Parry's Voyage for the discovery of a North-west Passage, in the years 1819-20. London. cxciii-ccx.

STEWART, D.B., and BERNIER, L.M.J. 1982. An aquatic resource survey of islands bordering Viscount Melville Sound, District of Franklin, Northwest Territories. Lands Directorate of Environment Canada and Northern Environment Branch of Indian and Northern Affairs, Land Use Information Series, Background Report No. 2. 110 p. Available at Department of Fisheries and Oceans Library, 501 University Crescent, Winnipeg, Manitoba R3T 2N6.

1983. An aquatic resource survey of Victoria and King William islands, and the northeastern District of Keewatin, Northwest Territories. Lands Directorate of Environment Canada and Northern Environment Branch of Indian and Northern Affairs, Land Use Information Series, Background Report No. 3. 124 p. Available at Department of Fisheries and Oceans Library, 501 University Crescent, Winnipeg, Manitoba R3T 2N6.

1984. An aquatic resource survey of Melville Peninsula, Southampton Island, and the northeastern District of Keewatin, Northwest Territories. Lands Directorate of Environment Canada and Northern Environment Branch of Indian and Northern Affairs, Land Use Information Series, Background Report No. 4. 144 p. Available at Department of Fisheries and Oceans Library, 501 University Crescent, Winnipeg, Manitoba R3T 2N6.

UNITED STATES DEPARTMENT OF THE INTERIOR. 1988. Final supplemental environmental impact statement: issuance of annual regulations permitting the sport hunting of migratory birds. Washington, D.C.: U.S. Fish and Wildlife Service. $340 \mathrm{p}$.

WILK. R.J. 1988. Distribution, abundance, population structure and productivity of tundra swans in Bristol Bay, Alaska. Arctic 41:288-292. 